\begin{tabular}{ll|l} 
Case Reports in & \multicolumn{2}{c}{ Case Rep Gastroenterol 2013;7:487-491 } \\
\cline { 2 - 3 } Gastroenterology & $\begin{array}{l}\text { DOI: 10.1159/000357151 } \\
\text { Published onlIne: November 19, 2013 }\end{array}$ & $\begin{array}{l}\text { ○ 2013 S. Karger AG, Basel } \\
\text { www.karger.com/crg }\end{array}$ \\
\hline & $\begin{array}{l}\text { This is an Open Access article licensed under the terms of the Creative Commons } \\
\text { Attribution-NonCommercial 3.0 Unported license (CC BY-NC) (www.karger.com/OA- } \\
\text { license), applicable to the online version of the article only. Distribution permitted for non- } \\
\text { commercial purposes only. }\end{array}$
\end{tabular}

\title{
Coil Migration after Transarterial Coil Embolization of a Splenic Artery Pseudoaneurysm
}

\author{
Bezawit D. Tekola David M. Arner Brian W. Behm \\ Division of Gastroenterology and Hepatology, Department of Medicine, University of \\ Virginia, Charlottesville, Va., USA
}

\section{Key Words}

Splenic artery pseudoaneurysm · Therapeutic embolization, adverse effects · Foreign bodies, diagnosis

\begin{abstract}
A 48-year-old man with a history of splenic artery pseudoaneurysm requiring transarterial embolization 3 months earlier presented to the emergency department with abdominal pain and fever. Computed tomography showed evidence of embolization coil fragments within the gastrointestinal tract. Upper endoscopy showed a large gastric ulcer with numerous embolization coils extruding into the gastric lumen. The patient underwent partial gastrectomy, distal pancreatectomy and resection of the splenic artery pseudoaneurysm. This case illustrates a rare delayed complication of transarterial embolization of a splenic artery pseudoaneurysm.

(c) 2013 S. Karger AG, Basel
\end{abstract}

\section{Introduction}

Splenic artery pseudoaneurysms are rare vascular abnormalities typically caused by sequelae of pancreatitis or abdominal trauma, and can lead to fatal bleeding complications if left untreated. The treatment options for splenic artery pseudoaneurysms include transarterial embolization, splenectomy or splenic artery ligation. In many medical centers transarterial embolization has supplanted surgery as the main management strategy because of high success rates and lower complication rates with embolization. However, both immediate and delayed complications occur with this procedure. This case report describes a patient who presented with a gastrosplenic artery fistula 3 months after transarterial coil embolization of a splenic artery pseudoaneurysm. 
Tekola et al.: Coil Migration after Transarterial Coil Embolization of a Splenic Artery Pseudoaneurysm

\section{Case Report}

A 48-year-old man with a prior history of renal transplantation was admitted to our medical center with 2 weeks of fever, chills and left upper quadrant abdominal pain. His history was significant for end-stage renal disease due to congenital solitary kidney and reflux nephropathy which required cadaveric renal transplantation in 2008. His immunosuppressive regimen included mycophenolate mofetil and tacrolimus. Three months prior to his current presentation he was admitted with Salmonella enteritidis bacteremia. During that hospitalization he was found to have a splenic artery pseudoaneurysm measuring $4.9 \times 5.1 \times$ $7.8 \mathrm{~cm}$ on abdominal computed tomography. This was suspected to be a mycotic pseudoaneurysm related to the Salmonella infection. After undergoing antibiotic treatment he subsequently underwent interventional radiology-guided coil embolization of the splenic artery pseudoaneurysm without complication.

At the time of his current admission, the patient reported 2 weeks of subjective fevers, intermittent chills and abdominal pain. The pain was located in the left upper quadrant, dull in quality, and was not associated with eating. On presentation he was afebrile and had normal vital signs. There were surgical scars from his prior renal transplant surgery. His abdominal exam was notable for mild tenderness in the left upper quadrant with normal bowel sounds. There was no guarding or rebound tenderness. Laboratory tests were notable for a mild leukocytosis and stable renal function (table 1). Blood and urine cultures were negative.

The patient had an abdominal X-ray revealing a fragment of embolization coil in the right lower quadrant (fig. 1). Abdominal/pelvic computed tomography with oral contrast revealed a migrated coil within the right colon (fig. 2). The remaining coils appeared to be within the splenic artery. There was no evidence of contrast extravasation or free intraperitoneal air. The patient subsequently underwent diagnostic upper endoscopy. This identified a large mucosal defect in the proximal stomach, with numerous coils extruding into the gastric lumen (fig. 3), consistent with a gastrosplenic artery fistula. The patient subsequently underwent exploratory laparotomy with splenectomy, distal pancreatectomy, partial gastrectomy, resection of the splenic artery aneurysm and removal of the splenic aneurysm coils. He had an uneventful recovery and was discharged from hospital 9 days after surgery.

\section{Discussion}

This case demonstrates a rare complication of transarterial coil embolization. Published reports describing vascular coil erosion into the gastrointestinal tract are limited. Takahashi et al. [1] reported coil erosion in the setting of a preexisting gastropseudocystic fistula with the incidental discovery of an early gastric cancer and subsequent surgical repair. Unlike our case, that report describes erosion through malignant tissue. Shah et al. [2] described a similar case of coil migration into the gastrointestinal tract through a preexisting pancreatic pseudocyst. That case, however, was managed conservatively with close observation. The remaining case reports found in the literature are different in that they describe various other extravascular coil erosions [3-7]. Finally, Mahajan et al. [5] described a case of coil erosion several months after embolization of bleeding duodenal varices. Interestingly, these were removed endoscopically with rat-toothed forceps under fluoroscopic guidance, as there were Amplatzer plugs purposely left behind to ensure hemostasis.

Although limited, the literature does describe transarterial embolization coil erosion into the gastrointestinal tract, thus making this a rare but known complication. The majority 
Tekola et al.: Coil Migration after Transarterial Coil Embolization of a Splenic Artery Pseudoaneurysm

of cases reported in the literature presented coil erosions as a delayed complication, the earliest reporting at 5 months and the latest at 10 years. Our case is unique in its early presentation, where the erosion occurred within 3 months of coil embolization. It is important to note that most of the described cases, including ours, involve evidence of infection at the fistulous site. This may suggest infection and inflammation at the site of the coil or adjacent structures as an inciting event in the process of transgastric erosion. Since there are not enough data in the literature about such complications, it is difficult to make recommendations on management. This case thus adds to the body of the existing literature with the primary goal of raising awareness of one of the rare complications of transarterial coil embolization.

\section{Disclosure Statement}

The authors have no financial disclosures to make. There was no grant support.

\section{References}

1 Takahashi T, Shimada K, Kobayashi N, Kakita A: Migration of steel-wire coils into the stomach after transcatheter arterial embolization for a bleeding splenic artery pseudoaneurysm: report of a case. Surg Today 2001;31:458-462.

$\checkmark 2$ Shah NA, Akingboye A, Haldipur N, Mackinlay JY, Jacob G: Embolization coils migrating and being passed per rectum after embolization of a splenic artery pseudoaneurysm, 'the migrating coil': a case report. Cardiovasc Intervent Radiol 2007;30:1259-1262.

-3 Bertges DJ, Villella ER, Makaroun MS: Aortoenteric fistula due to endoleak coil embolization after endovascular AAA repair. J Endovasc Ther 2003;10:130-135.

4 Dinter DJ, Rexin M, Kaehler G, Neff W: Fatal coil migration into the stomach 10 years after endovascular celiac aneurysm repair. J Vasc Interv Radiol 2007;18:117-120.

5 Mahajan A, Kumer SC, Wang AY: Electronic images of the month. Duodenal ulceration following variceal embolization with coils and vascular plugs. Clin Gastroenterol Hepatol 2010;8:e63-e64.

6 Ozkan OS, Walser EM, Akinci D, Nealon W, Goodacre B: Guglielmi detachable coil erosion into the common bile duct after embolization of iatrogenic hepatic artery pseudoaneurysm. J Vasc Interv Radiol 2002;13: 935-938.

7 Yoon JW, Koo JR, Baik GH, Kim JB, Kim DJ, Kim HK: Erosion of embolization coils and guidewires from the kidney to the colon: delayed complication from coil and guidewire occlusion of renal arteriovenous malformation. Am J Kidney Dis 2004;43:1109-1112. 
Tekola et al.: Coil Migration after Transarterial Coil Embolization of a Splenic Artery Pseudoaneurysm

Table 1. Laboratory results

\begin{tabular}{lll}
\hline Component & Result & Reference range \\
\hline White blood cells, $\times 10^{3} / \mu \mathrm{l}$ & 12.5 & $4-11$ \\
Hemoglobin, g/dl & 14.2 & $14-18$ \\
Platelets, $\times 10^{3} / \mu \mathrm{l}$ & 329 & $150-450$ \\
Potassium, mmol/l & 4.8 & $3.4-4.8$ \\
BUN, mg/dl & 12 & $8.4-25.7$ \\
Creatinine, mg/dl & 1.1 & $0.7-1.3$ \\
ALP, U/l & 139 & $<150$ \\
ALT, U/l & 12 & $<55$ \\
AST, U/l & 17 & $<35$ \\
Total bilirubin, mg/dl & 0.3 & $0.3-1.2$ \\
Albumin, g/dl & 4.2 & $3.2-5.2$ \\
Lipase, U/l & 20 & $8-78$ \\
\hline
\end{tabular}

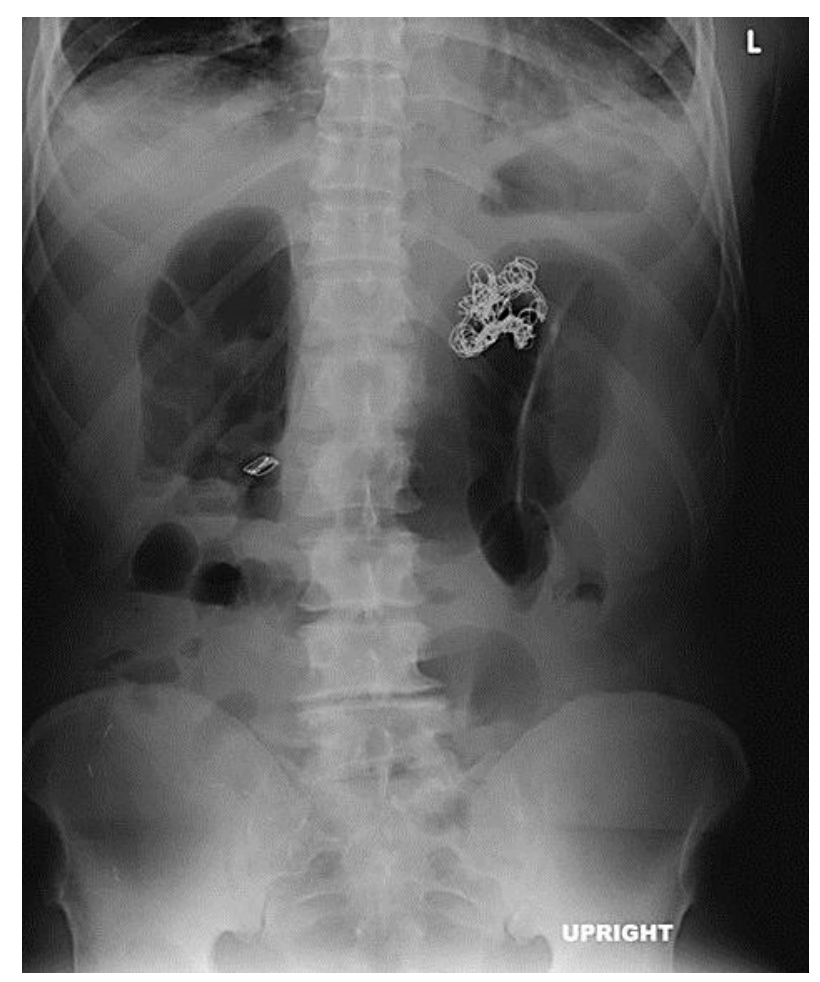

Fig. 1. Abdominal X-ray showing a coil fragment in the right lower quadrant. 


\begin{tabular}{ll|l} 
Case Reports in & \multicolumn{2}{l}{} \\
\cline { 2 - 3 } Gastroenterology & Case Rep Gastroenterol 2013;7:487-491 & $\begin{array}{l}\text { ○ } 2013 \text { S. Karger AG, Basel } \\
\text { www.karger.com/crg }\end{array}$ \\
\cline { 2 - 3 } & DOI: 10.1159/000357151 & $\begin{array}{l}\text { Tekola et al.: Coil Migration after Transarterial Coil Embolization of a Splenic Artery } \\
\text { Pseudoaneurysm }\end{array}$
\end{tabular}

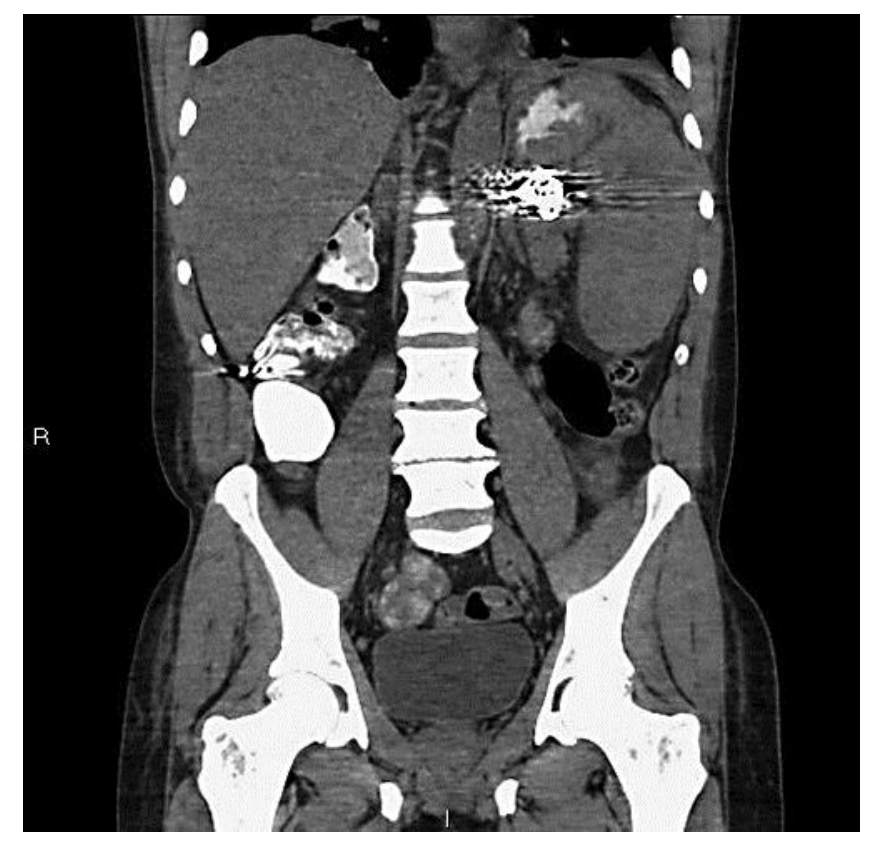

Fig. 2. Abdominal/pelvic computed tomography confirming a coil fragment in the ascending colon.
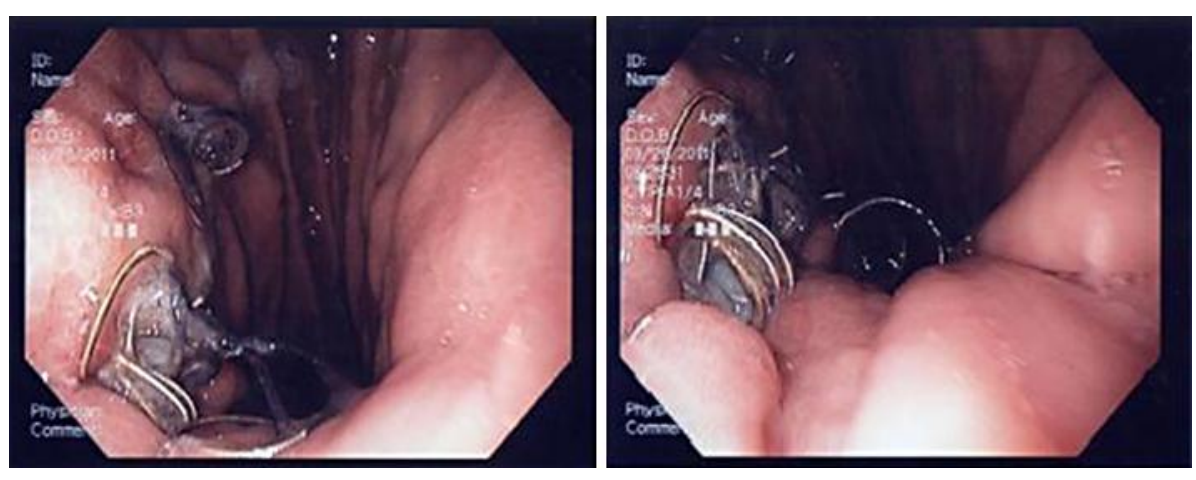

Fig. 3. Endoscopic view of coils eroding through the gastric wall. 